\title{
ANALISIS RISIKO PENGOPERASIAN \\ OVERHEAD CRANE DOUBLE GIRDER DI DIVISI KAPAL NIAGA PT PAL SURABAYA
}

\author{
Ryan Rizky Bikatofani \\ Persatuan Alumni Kesehatan Masyarakat Indonesia \\ (PERSAKMI) Provinsi Jawa Timur \\ E-mail: ryanrizkyb92@gmail.com
}

\begin{abstract}
PT. PAL Surabaya operates Overhead Crane Double Girder tool every day. Those have some risks, for example squeezed, material crushed, fracture and passed away. The objective of the research was to value the level of risks on kapal niaga division PT. PAL Surabaya. The type of this research was descriptive observational research with cross sectional approach. The research focuses on overhead crane double girder operation at kapal niaga division PT PAL Surabaya, consists of operation phase itself. Primary data collection by doing interview and observation, it was presented in a table, analyzed, and explained in descriptive way. The result showed there were 8 potential hazards on operation phase. Controlling type that most implementated was providing personal protective equipment (PPE) as $75 \%$. That is quite significant and effective although there were still residual risks on 7 low potential hazards on preparation phase and 1 medium potential hazards on operation phase. PT PAL Surabaya has not done measurement the level of risks and suggested to do identification in details by noticing any hazards and risks in every job phase. Besides, the operator from the whole overhead crane double girder operation should have K3 (SIO) license and specific experience in operating overhead crane double girder, this suitable with Permenaker No 09/MEN/VII/2010.
\end{abstract}

Keywords: risk assessment, overhead crane double girder, level of risks

\begin{abstract}
ABSTRAK
PT PAL Surabaya mengoperasikan alat overhead crane double girder setiap hari. Dalam mengoperasikan alat terdapat risiko seperti terjepit, tertimpa material, patah tulang hingga meninggal dunia. Tujuan dari penelitian ini adalah untuk menilai tingkat risiko yang ada di divisi kapal niaga PT PAL Surabaya. Penelitian ini merupakan jenis penelitian observasional deskriptif dengan pendekatan cross sectional. Penelitian ini berfokus pada pengoperasian overhead crane double girder di divisi kapal niaga PT PAL Surabaya. Data primer didapatkan melalui wawancara dan observasi yang disajikan dalam tabel kemudian dianalisis dan dijabarkan dalam perumusan deskriptif. Hasil penilaian risiko yang dilakukan menemukan 8 potensi bahaya pada tahap pengoperasian. Jenis pengendalian yang paling banyak diimplementasikan adalah dengan penyediaan alat pelindung diri (APD) kepada pekerja sebesar 75\%. Pada tahap pengoperasian terdapat risiko sisa sebanyak 7 potensi bahaya tingkat rendah dan 1 potensi bahaya tingkat sedang. Pihak PT PAL Surabaya belum melakukan penilaian tingkat risiko yang ada pada pengoperasian alat overhead crane double girder dan disarankan untuk melaksanakan pengidentifikasian secara terperinci dengan melihat bahaya dan risiko pada setiap tahap pekerjaan, selain itu operator dari overhead crane double girder keseluruhannya harus memiliki lisensi K3 (SIO) dan berpengalaman khusus dalam pengoperasian overhead crane double girder sesuai dengan Permenaker No 09/MEN/VII/2010.
\end{abstract}

Kata kunci: penilaian risiko, overhead crane double girder, tingkat risiko

\section{PENDAHULUAN}

Menurut Hinze (1997), pekerjaan di bidang konstruksi adalah satu bidang pekerjaan yang memiliki tingkat risiko yang tinggi dalam pelaksanaannya. Hal ini disebabkan banyak pekerjaan bidang konstruksi selalu berada di tempat yang terbuka, memiliki kemudahan akses untuk dimasuki oleh orang-orang yang berbeda setiap waktu, serta melibatkan proses pekerjaan dengan alat-alat yang berpotensi menimbulkan kecelakaan kerja yang cukup tinggi sehingga kondisi tersebut kurang mendukung untuk pelaksanaan keselamatan dan kesehatan kerja (K3). Sehingga, dapat memiliki potensi bahaya untuk menyebabkan terjadinya suatu kecelakaan kerja, salah satunya adalah alat angkat dan angkut yaitu overhead crane double girder.

Menurut Undang-Undang Republik Indonesia Nomor 18 Tahun 1999 mengenai Jasa Konstruksi bahwa pekerjaan konstruksi merupakan keseluruhan atau sebagian rangkaian kegiatan perencanaan 
dan atau pelaksanaan beserta pengawasan yang mencakup pekerjaan arsitektural, sipil, mekanikal, elektrikal dan tata lingkungan masing-masing beserta kelengkapannya untuk mewujudkan suatu bangunan atau bentuk fisik lain.

Pada proses pelaksanaan pekerjaan konstruksi banyak membutuhkan tenaga kerja yang dapat meningkatkan taraf hidup serta mengurangi tingkat pengangguran yang sekarang ini sedang banyak terjadi. Menurut data yang diperoleh dari Departemen Tenaga Kerja dan Transmigrasi (2009) menyebutkan bahwa kehadiran perusahaan layanan jasa konstruksi semakin bertambah dan mampu menyerap sekitar 4,5 juta tenaga kerja di Indonesia. Menurut Wicaksono (2011) menyatakan proses pembangunan konstruksi dapat menimbulkan dampak negatif seperti dapat terjadinya suatu kecelakaan kerja. Kecelakaan yang timbul dapat dikategorikan dari kecelakaan minor hingga kecelakaan yang fatal juga memiliki potensi yang besar untuk terjadi di pekerjaan dalam bidang konstruksi. Dampak yang dapat terjadi pun juga tidak kecil, mulai dari kerugian yang dapat dialami oleh pekerja seperti luka-luka, kecacatan bahkan hingga dapat menyebabkan meninggal dunia, pihak perusahaan pun juga akan mengalami kerugian dengan mengeluarkan biaya kompensasi kepada para pekerja yang menjadi korban kecelakaan kerja.

Berdasarkan penelitian yang dilakukan oleh Hinze (1997), industri konstruksi menempati urutan tertinggi apabila dilihat dari terjadinya kecelakaan kerja dan kematian, sedangkan menurut Lestari (2013), menyebutkan bahwa sektor konstruksi di Indonesia menempati urutan tertinggi dalam kecelakaan kerja yakni sebesar 32\%.

Kecelakaan kerja dapat terjadi karena dua penyebab, yaitu kondisi tidak aman (unsafe condition) dan tindakan tidak aman (unsafe act) (Reason,1997). Menurut Soputan (2014), kecelakaan kerja yang terjadi tidak disebabkan oleh satu faktor saja, melainkan banyak faktor yang menjadi pemicu terjadinya suatu kecelakaan, khususnya di sektor konstruksi. Selain itu tingginya kasus kecelakaan kerja juga akan merugikan banyak pihak terutama tenaga kerja yang bersangkutan. Menurut Bird (1990), menyatakan bahwa diantara faktor yang menjadi penyebab kecelakaan kerja adalah perilaku yang tidak aman, serta berbagai penyebab dasarnya adalah faktor individu dan pekerjaan. Perilaku tidak aman tersebut dapat digambarkan oleh pekerja itu sendiri, mandor, pengawas, pelaksana maupun pihak manajer Kecelakaan kerja yang terjadi di bidang konstruksi sebanyak $90 \%$ hampir selalu disebabkan oleh perilaku pekerja yang tidak aman, sedangkan $10 \%$ sisanya disebabkan oleh kondisi tidak aman (Hinze, 1997).

Overhead travelling crane merupakan salah satu jenis kran yang banyak digunakan dalam kegiatan pekerjaan di bidang sektor konstruksi, yang berupa jembatan melintang diatas kepala yang umumnya terbuat konstruksi rangka batang yang ditutup atau dilapis plat baja. Mekanisme ini juga sering disebut troli yang dilengkapi dengan alat-alat hingga sedemikian rupa yang dapat menghasilkan beberapa gerakan antara lain seperti pengangkatan benda (hoisting system) dan jalan melintang pada jembatan (Anizar, 2009).

Besarnya risiko terjadinya kecelakaan kerja akibat crane adalah dengan terjadinya beberapa kasus kecelakaan kerja yang sudah ada di mana pada setiap kejadian kecelakaan kerja yang ada biasanya selalu menyebabkan cidera pada korbannya mulai dari cidera ringan seperti memar, lalu dapat menyebakan patah tulang dan bahkan dapat menyebabkan hingga meninggal dunia pada korbannya.

Berdasarkan Peraturan Menteri Tenaga Kerja Republik Indonesia No: PER.05/MEN/1985 Tentang Pesawat Angkat Dan Angkut menyatakan bahwa dengan meningkatnya pembangunan dan teknologi di bidang industri, penggunaan pesawat angkat dan angkut merupakan bagian integral dalam pelaksanaan dan peningkatan proses produksi, dan dalam pembuatan, pemasangan, pemakaian, perawatan, pesawat angkat dan angkut mengandung bahaya potensial dan perlu adanya perlindungan atas keselamatan dan kesehatan kerja setiap tenaga kerja yang melakukan pembuatan, pemasangan, pemakaian, persyaratan pesawat angkat dan angkut, maka setiap perusahaan yang mempergunakan pesawat uap wajib menyelenggarakan program keselamatan dan kesehatan kerja, dengan tujuan untuk mengurangi timbulnya bahaya yang dapat mengganggu aktivitas produksi dan manusia.

Selain itu menurut Peraturan Menteri Tenaga Kerja Dan Transmigrasi Republik Indonesia Nomor PER.09/MEN/VII/2010 Tentang Operator Dan Petugas Pesawat Angkat Angkut juga telah dijelaskan syarat-syarat dan kualifikasi operator pesawat angkat angkut sesuai dengan masing-masing bidang yang dikerjakan supaya dapat menurunkan risiko terjadinya kecelakaan kerja pada saat pengoperasian alat overhead crane double girder. Menurut OHSAS 18001 (2007), upaya yang dapat dilakukan untuk mengurangi bahaya terjadinya kecelakaan kerja 
dapat dilakukan dengan cara pembuatan risk assessment and risk management terhadap setiap aktivitas pekerjaan yang dikerjakan supaya dapat mengetahui seberapa besar tingkat risiko yang ada dan juga dapat menentukan langkah pengendalian seperti apakah yang dapat dilakukan berdasarkan tingkat risiko yang ada pada suatu proses pekerjaan tersebut.

PT PAL Surabaya adalah perusahaan yang memproduksi kapal perang dan kapal niaga, memberikan jasa perbaikan dan pemeliharaan kapal, serta rekayasa umum dengan spesifikasi tertentu berdasarkan pesanan. Divisi kapal niaga merupakan salah satu divisi yang ada di PT PAL Surabaya yang berada langsung di bawah Direktorat Pembangunan Kapal yang memproduksi kapal-kapal niaga yang berkualitas internasional seperti Dry Cargo Veseel, Bulk Carrier, Tanker, Container.

Divisi kapal niaga didalamnya terdapat 7 alat overhead crane double girder yang memiliki kapasitas sebesar 10 ton sebanyak 2 buah, 20 ton sebanyak 1 buah, 30 ton sebanyak 1 buah, 38 ton sebanyak 1 buah, 40 ton sebanyak 1 buah dan 150 ton sebanyak 1 buah. Pada PT PAL Surabaya sendiri khususnya di divisi kapal niaga belum melakukan penilaian tingkat risiko pada pengoperasian alat overhead crane double girder sehingga peneliti merasa perlu melakukan penilaian tingkat risiko pengoperasian alat overhead crane double girder.

Tujuan penelitian ini adalah mengetahui tingkat risiko kecelakaan kerja pada pengoperasian alat overhead crane double girder di divisi kapal niaga PT PAL Surabaya.

\section{METODE}

Penelitian yang dilakukan merupakan penelitian observasional deskriptif dengan menggunakan metode cross sectional. Jumlah responden yang digunakan dalam penelitian ini adalah menggunakan total populasi yang ada yaitu 3 orang pihak safety dan 29 operator dan rigger pada alat overhead crane double girder. Penelitian ini dilakukan di divisi kapal niaga PT PAL Surabaya. Sedangkan, waktu penelitian dilaksanakan pada bulan Mei - Juni 2015.

Teknik pengumpulan data dilaksanakan dengan mengambil data primer dan data sekunder. Data primer meliputi lembar observasi mengenai identifikasi bahaya, kemudian setelah dilakukan identifikasi bahaya perlu dilakukan penilaian tingkat risiko yang ada, kemudian melakukan penilaian pengendalian risiko yang ada, dan melakukan penilaian risiko sisa pada pengoperasian overhead crane double girder di PT PAL Surabaya.

Wawancara dilakukan kepada 12 operator, 17 rigger serta 3 orang pihak safety yang ada guna mendapatkan informasi yang berkaitan dengan alat overhead crane double girder di divisi kapal niaga PT PAL Surabaya, sedangkan untuk data sekunder meliputi gambaran umum perusahaan dan data kecelakaan kerja khususnya di divisi kapal niaga PT PAL Surabaya. Data yang diperoleh akan dianalisis secara deskriptif, kemudian hasilnya disajikan dalam bentuk tabel, narasi dan juga gambar.

\section{HASIL}

Divisi kapal niaga adalah salah satu dari divisi yang dimiliki PT PAL Indonesia (Persero) yang berada langsung di bawah Direktorat Pembangunan Kapal yang memproduksi kapal-kapal niaga berkualitas internasional seperti Dry Cargo Veseel, Bulk Carrier, Tanker, Container. Dalam upaya untuk memenuhi OHSAS 1800:2007 klausul 4.3.1 "identifikasi risiko, penilaian risiko dan pengendalian risiko" bahwa kegiatan identifikasi bahaya, penilaian risiko dan pengendalian risiko dilaksanakan dalam operasional kerja yang ada di dalam suatu perusahaan. Teknik identifikasi bahaya yang dilakukan pada divisi kapal niaga PT PAL adalah dengan menggunakan lembar Job Safety Analysis (JSA). Teknik ini lebih memudahkan untuk meneliti bahaya pada setiap langkah-langkah pekerjaan pengoperasian overhead crane double girder, kemudian mencari pengendalian bahayanya sehingga bahaya dapat dikendalikan sejak dini dan menghindari terjadinya kecelakaan.

Overhead crane (OHC) termasuk dalam kategori peralatan angkat seperti diatur dalam Permenaker RI. No. 05 Tahun 1985 tentang Pesawat Angkat dan Angkut. Pesawat angkat dan angkut sendiri adalah suatu pesawat atau alat yang digunakan untuk memindahkan, mengangkat muatan baik bahan atau barang atau orang secara vertical dan atau horizontal dalam jarak yang ditentukan. Sedangkan peralatan angkat adalah alat yang dikonstruksi atau dibuat khusus untuk mengangkat naik dan menurunkan muatan (Kemenakertrans RI, 2011).

Overhead crane adalah salah satu jenis dari peralatan transportasi mekanikal yang ada. Fungsi dari alat ini adalah untuk memindahkan atau untuk mengangkat muatan material dari tempat yang satu ke tempat yang lain. Overhead crane pada 
umumnya terdiri dari 3 jenis, yaitu single girder, single girder beam, double girder. Single girder beam termasuk ke dalam single girder karena pada struktur girder terbuat dari struktur beam atau baja. Sedangkan perbedaan dari single girder dan double girder hanyalah terletak pada jumlah girder dan juga dari struktur girder untuk keduanya dibuat dari plat baja yang dibentuk sedemikian rupa hingga dapat menjadi kotak (box) (Anizar, 2009).

Overhead crane double girder memiliki beberapa fungsi seperti crossing/travelling yang berarti kemampuan dari alat untuk memindahkan material/bahan yang telah diangkat sebelumnya. Selain itu terdapat juga fungsi lowering yaitu kemampuan alat untuk menurunkan material/ bahan yang akan/telah dipindahkan, dan terdapat pula fungsi lifting/hoisting yaitu kemampuan alat untuk mengangkat material/bahan yang akan/telah dipindahkan (Anizar, 2009).

Proses pengoperasian dari overhead crane dapat dimulai dengan beberapa tahap pekerjaan antara lain mulai dari memastikan terlebih dahulu berat beban dari material yang akan diangkat dan dipindahkan tidak melebihi dari standard weight limit (SWL) yang ada pada overhead crane itu sendiri. Hal ini penting dilakukan juga supaya dari awal sudah diketahui dan dapat direncanakan akan menggunakan alat overhead crane double girder yang memiliki daya angkat dan angkut yang sesuai dengan berat beban atau material yang akan diangkat maupun dipindahkan.

Tahap selanjutnya adalah memilih sling + segel yang akan digunakan. Dalam tahap ini juga harus benar-benar dipastikan sling + segel yang digunakan sesuai dengan kapasitas OHC yang akan digunakan supaya dapat mengurangi risiko terjadinya kecelakaan kerja akibat tali sling yang dapat putus. Apabila kedua tahap sebelumnya telah dilaksanakan maka tahap selanjutnya adalah menggunakan $\mathrm{klem}$ untuk mengikat beban yang akan diangkat atau dipindahkan oleh overhead crane. Memilih klem yang akan digunakan pun juga harus tepat supaya alat dapat berfungsi dengan baik dan sebagaimana mestinya.

Tahap pekerjaan selanjutnya adalah memastikan posisi beban/material yang akan diangkat dalam posisi tegak lurus dengan hook. Tahap ini menjadi penting untuk selalu dilakukan pengawasan oleh pihak safety yang ada karena biasanya pada tahap ini lah sering terjadi pekerja yang terkena material yang berayun pada saat akan dilaksanakan proses pengangkatan maupun penurunan material/beban pada saat mengangkat material atau beban nya tidak berada dalam posisi yang tegak lurus. Koordinasi antara pihak safety, rigger dan juga operat sangat diperlukan. Tahapan pekerjaan selanjutnya adalah memastikan area/lintasan yang akan dilewati oleh overhead crane dalam keadaan yang steril/aman. Hal ini bertujuan supaya apabila saat alat overhead crane double girder beroperasi sudah tidak terdapat lagi pekerja yang berada di bawah atau di sekitarnya.

Semua tahap sebelumnya apabila telah dilewati dengan baik maka material/beban yang akan diangkat oleh overhead crane dapat mulai diangkat secara perlahan-lahan. Penting untuk tetap selalu diawasi supaya beban yang diangkat tidak bergoyang dan harus dipastikan pula pada dasar dari beban/ material yang diangkat dalam kondisi yang aman. Tahapan pekerjaan selanjutnya adalah memastikan bahwa rigger harus mengawal material/beban yang akan diangkat selama proses pengangkatan \& penurunan material/beban. Pada saat ini rigger dan operator juga harus memastikan bahwa sirine yang ada pada alat berfungsi dengan baik sebagai penanda bahwa alat sedang beroperasi.

Tahapan pekerjaan terakhir adalah memastikan bahwa beban/material yang diturunkan berada di tempat yang sesuai/aman. Tahap ini menandakan bahwa segala proses telah selesai dilaksanakan, kemudian dalam melaksanakan penilaian tingkat risiko yang ada maka langkah pertama yang dilakukan adalah dengan melakukan identikasi bahaya yang dapat terjadi pada setiap aktivitas dari pekerjaan yang akan dilaksanakan pada saat proses pengoperasian alat overhead crane double girder. Berikut merupakan hasil identifikasi bahaya yang terdapat pada proses pengoperasian overhead crane double girder yang dapat dilihat pada Tabel 1 .

Tahap setelah identifikasi bahaya pada setiap langkah pekerjaan yang ada, adalah dengan melakukan suatu penilaian tingkat risiko yang ada pada pekerjaan pengoperasian alat overhead crane double girder, untuk mendapatkan nilai dari tingkat risiko yang dihasilkan dapat dengan menggunakan kriteria likelihood (kemungkinan) dikalikan dengan severity (keparahan).

Hasil perkalian tersebut akan menghasilkan nilai yang dapat menunjukkan seberapa besar tingkat risiko yang dihasilkan pada saat proses pengoperasian alat overhead crane double girder apakah dapat diterima atau tidak. Jika tingkat risiko yang dihasilkan pada tahap pengoperasian alat overhead crane double girder dapat diterima maka maka suatu pada pekerjaan dapat diteruskan kembali 
Tabel 1. Identifikasi Bahaya Overhead Crane Double Girder

\begin{tabular}{|c|c|}
\hline Tahapan Pekerjaan & Potensi Bahaya \\
\hline Memastikan berat beban/material yang akan diangkat/dipindahkan tidak melebihi SWL. & Tergores material \\
\hline $\begin{array}{l}\text { Memilih sling + segel yang akan digunakan untuk mengangkat/ memindahkan material atau } \\
\text { bahan. }\end{array}$ & Tergores material \\
\hline Menggunakan hook untuk mengikat beban/material yang akan diangkat atau di pindahkan. & Terjepit material \\
\hline $\begin{array}{l}\text { Memastikan posisi beban/material yang akan di angkat atau dipindahkan mempunyai posisi } \\
\text { tegak lurus dengan hook dan tali rop. }\end{array}$ & Material Berayun \\
\hline $\begin{array}{l}\text { Memastikan area/lintasan yang akan dilewati oleh overhead crane double girder dalam kondisi } \\
\text { yang aman/ steril. }\end{array}$ & Tersandung material \\
\hline Mengangkat beban/material secara perlahan-lahan. & Tertimpa material \\
\hline $\begin{array}{l}\text { Memastikan bahwa rigger mengawal material/bahan yang akan diangkat atau dipindahkan } \\
\text { selama proses pengangkatan dan juga untuk penurunan. }\end{array}$ & Tertimpa material \\
\hline $\begin{array}{l}\text { Memastikan beban/ material yang telah diangkat/dipindahkan akan di turunkan di tempat yang } \\
\text { aman dan sesuai. }\end{array}$ & Terjepit \\
\hline
\end{tabular}

seperti biasanya, akan tetapi tetap memerlukan pengawasan dari pihak safety yang bertugas yang berasal dari pihak perusahaan itu sendiri.

Nilai tingkat risiko yang dihasilkan pada pengoperasian alat overhead crane double girder apabila tidak dapat diterima maka perlu dilakukan suatu pengendalian risiko yang lebih lanjut lagi dan juga harus memperhatikan tingkat keefektifan dari program pengendalian yang dibuat supaya dapat mencapai tujuan dari perusahaan yaitu untuk dapat menurunkan atau mengurangi dampak yang mungkin saja terjadi.
Tingkat risiko yang dimaksud adalah tingkat rendah (low), tingkat sedang (medium), dan tingkat tinggi (high), sedangkan evaluasi risiko akan menunjukkan masih diterima ataukah tidak risiko yang dihasilkan dan bertujuan untuk menekan tingkat risiko yang dapat terjadi (Ramli, 2010ª).

Tabel 2 berikut akan menunjukkan hasil perhitungan dari tingkat risiko yang dihasilkan pada proses pengoperasian alat overhead crane double girder di divisi kapal niaga PT PAL Surabaya:

Tahap setelah mengetahui tingkat risiko yang dihasilkan adalah dengan melakukan pengendalian

Tabel 2. Penilaian Risiko Pengoperasian Alat Overhead Crane Double Girder

\begin{tabular}{|c|c|c|c|c|c|}
\hline \multirow[b]{2}{*}{ Aktivitas Pekerjaan } & \multirow[b]{2}{*}{ Bahaya } & \multirow[b]{2}{*}{ Risiko } & \multicolumn{2}{|c|}{ Penilaian Risiko } & \multirow[b]{2}{*}{$\begin{array}{l}\text { Tingkat } \\
\text { Risiko }\end{array}$} \\
\hline & & & $\begin{array}{l}\text { Likeli- } \\
\text { hood }\end{array}$ & severity & \\
\hline $\begin{array}{l}\text { Memastikan berat beban/material yang akan } \\
\text { diangkat/ dipindahkan tidak melebihi SWL }\end{array}$ & $\begin{array}{l}\text { Tergores } \\
\text { material }\end{array}$ & $\begin{array}{l}\text { Cidera pada tangan } \\
\text { atau kaki, memar }\end{array}$ & 3 & 2 & 6 \\
\hline $\begin{array}{l}\text { Memilih sling }+ \text { segel yang akan digunakan untuk } \\
\text { mengangkat atau memindahkan material atau bahan }\end{array}$ & $\begin{array}{l}\text { Tergores } \\
\text { material }\end{array}$ & $\begin{array}{l}\text { Cidera pada tangan } \\
\text { atau kaki, memar }\end{array}$ & 3 & 2 & 6 \\
\hline $\begin{array}{l}\text { Menggunakan hook untuk mengikat beban/ material } \\
\text { yang akan diangkat/di pindahkan. }\end{array}$ & $\begin{array}{l}\text { Terjepit } \\
\text { material }\end{array}$ & $\begin{array}{l}\text { Cidera pada tangan } \\
\text { atau kaki, memar }\end{array}$ & 3 & 3 & 9 \\
\hline $\begin{array}{l}\text { Memastikan posisi beban/material yang akan di } \\
\text { angkat atau di pindahkan mempunyai posisi tegak } \\
\text { lurus dengan hook }\end{array}$ & $\begin{array}{l}\text { Terkena } \\
\text { ayunan } \\
\text { material }\end{array}$ & $\begin{array}{l}\text { Cidera parah, } \\
\text { hingga meninggal }\end{array}$ & 3 & 5 & 15 \\
\hline $\begin{array}{l}\text { Memastikan area/lintasan yang akan dilewati oleh } \\
\text { overhead crane double girder dalam kondisi yang } \\
\text { aman/steril. }\end{array}$ & $\begin{array}{l}\text { Tersandung } \\
\text { material }\end{array}$ & $\begin{array}{l}\text { Cidera pada tangan } \\
\text { atau kaki, memar }\end{array}$ & 3 & 2 & 6 \\
\hline Mengangkat beban/material secara perlahan-lahan. & $\begin{array}{l}\text { Tertimpa } \\
\text { material }\end{array}$ & $\begin{array}{l}\text { Cidera parah, } \\
\text { hingga meninggal }\end{array}$ & 2 & 5 & 10 \\
\hline $\begin{array}{l}\text { Memastikan bahwa rigger mengawal material/bahan } \\
\text { yang akan diangkat atau dipindahkan selama proses } \\
\text { pengangkatan dan penurunan. }\end{array}$ & $\begin{array}{l}\text { Tertimpa } \\
\text { material }\end{array}$ & $\begin{array}{l}\text { Cidera parah, } \\
\text { hingga meninggal }\end{array}$ & 2 & 5 & 10 \\
\hline $\begin{array}{l}\text { Memastikan beban/material yang telah diangkat atau } \\
\text { dipindahkan akan di turunkan di tempat yang aman } \\
\text { dan sesuai }\end{array}$ & Terjepit & $\begin{array}{l}\text { Cidera pada tangan } \\
\text { atau kaki, memar }\end{array}$ & 3 & 3 & 9 \\
\hline
\end{tabular}


dari setiap risiko yang ada pada tahapan pekerjaan yang ada di dalam proses pengoperasian alat overhead crane double girder. Pengendalian risiko menjadi salah satu tahap yang juga sangat penting untuk dilaksanakan karena pada tahap inilah perusahaan harus dapat memilih dengan cermat pengendalian risiko seperti apakah yang memang paling efektif untuk diterapkan dan sesuai dengan hasil dari tingkat risiko yang dihasilkan pada proses pengoperasian alat overhead crane double girder.

Pengendalian risiko yang akan diterapkan oleh pihak perusahaan harus berdasar hasil penilaian risiko yang ada sebelumnya supaya sesuai dengan hasil tingkat risiko yang dihitung sebelumnya dan hasilnya dapat sesuai dengan tujuan.
Pengendalian risiko ini dilakukan berdasarkan dari perhitungan tingkat risiko yang dihasilkan pada proses pengoperasian alat Overhead Crane Double Girder di Divisi Kapal Niaga. PT PAL Surabaya menerapkan 3 langkah pengendalian risiko yang ada, antara lain: Pengendalian secara teknik, pengendalian secara administratif dan penyediaan Alat Pelindung Diri (APD).

Upaya pengendalian yang sudah dilakukan oleh PT PAL, Surabaya akan disesuaikan dengan pengendalian risiko sesuai dengan tabel penilaian efektivitas. Dari Tabel 3 akan menunjukkan hasil dari pengendalian risiko yang ada pada proses pengoperasian alat overhead crane double girder:

Tabel 3. Pengendalian Risiko pada Pengoperasian Overhead Crane Double Girder

\begin{tabular}{|c|c|c|c|c|c|c|c|}
\hline \multirow{2}{*}{ Aktivitas Pekerjaan } & \multirow{2}{*}{ Bahaya } & \multicolumn{2}{|c|}{ Penilaian Risiko } & \multirow{2}{*}{$\begin{array}{l}\text { Tingkat } \\
\text { Risiko }\end{array}$} & \multirow{2}{*}{$\begin{array}{c}\text { Pengendalian } \\
\text { Risiko }\end{array}$} & \multirow{2}{*}{ Implementasi } & \multirow{2}{*}{$\begin{array}{c}\text { Penilaian } \\
\text { Pengendalian } \\
\text { Risiko }\end{array}$} \\
\hline & & $\begin{array}{c}\text { Likeli- } \\
\text { hood }\end{array}$ & Severity & & & & \\
\hline $\begin{array}{l}\text { Memastikan berat } \\
\text { beban/material } \\
\text { yang akan diangkat/ } \\
\text { dipindahkan tidak } \\
\text { melebihi SWL }\end{array}$ & $\begin{array}{l}\text { Tergores } \\
\text { material }\end{array}$ & 3 & 2 & 6 & $\begin{array}{l}\text { Menggunakan } \\
\text { APD (sarung } \\
\text { tangan, helm, } \\
\text { safety shoes) }\end{array}$ & $\begin{array}{l}\text { Persyaratan } \\
\text { kontrol yang ada } \\
\text { diimplementasikan } \\
\text { dengan cukup baik. }\end{array}$ & $65 \%$ \\
\hline $\begin{array}{l}\text { Memilih sling }+ \text { segel } \\
\text { yang akan digunakan } \\
\text { sesuai dengan beban } \\
\text { yang akan diangkat. }\end{array}$ & $\begin{array}{l}\text { Terjepit } \\
\text { material }\end{array}$ & 3 & 3 & 9 & $\begin{array}{l}\text { Menggunakan } \\
\text { APD (sarung } \\
\text { tangan, helm, } \\
\text { safety shoes) }\end{array}$ & $\begin{array}{l}\text { Persyaratan } \\
\text { kontrol yang ada } \\
\text { diimplemntasikan } \\
\text { dengan cukup baik. }\end{array}$ & $65 \%$ \\
\hline $\begin{array}{l}\text { Menggunakan klem } \\
\text { untuk mengikat } \\
\text { beban/material yang } \\
\text { akan diangkat atau di } \\
\text { pindahkan. }\end{array}$ & $\begin{array}{l}\text { Terjepit } \\
\text { material }\end{array}$ & 3 & 3 & 9 & $\begin{array}{l}\text { Menggunakan } \\
\text { APD (sarung } \\
\text { tangan, helm, } \\
\text { safety shoes) }\end{array}$ & $\begin{array}{l}\text { Persyaratan } \\
\text { kontrol yang ada } \\
\text { diimplementasikan } \\
\text { dengan cukup baik. }\end{array}$ & $65 \%$ \\
\hline $\begin{array}{l}\text { Memastikan posisi } \\
\text { beban/material yang } \\
\text { akan di angkat atau } \\
\text { akan di pindahkan } \\
\text { mempunyai posisi } \\
\text { tegak lurus dengan } \\
\text { hook }\end{array}$ & $\begin{array}{l}\text { Terkena } \\
\text { ayunan } \\
\text { material }\end{array}$ & 3 & 5 & 15 & $\begin{array}{l}\text { Menggunakan } \\
\text { APD (sarung } \\
\text { tangan, helm, } \\
\text { safety shoes) }\end{array}$ & $\begin{array}{l}\text { Persyaratan } \\
\text { kontrol yang ada } \\
\text { diimplementasikan } \\
\text { dengan cukup baik. }\end{array}$ & $65 \%$ \\
\hline $\begin{array}{l}\text { Memastikan area/ } \\
\text { lintasan yang } \\
\text { akan dilewati oleh } \\
\text { overhead crane } \\
\text { double girder dalam } \\
\text { kondisi yang aman/ } \\
\text { steril. }\end{array}$ & $\begin{array}{l}\text { Tersandung } \\
\text { material }\end{array}$ & 3 & 2 & 6 & $\begin{array}{l}\text { Melakukan } \\
\text { house keeping } \\
\text { pada sisa-sisa } \\
\text { material yang } \\
\text { ada }\end{array}$ & $\begin{array}{l}\text { Persyaratan } \\
\text { kontrol yang ada } \\
\text { diimplemntasikan } \\
\text { dengan cukup baik. }\end{array}$ & $65 \%$ \\
\hline $\begin{array}{l}\text { Mengangkat beban/ } \\
\text { material secara } \\
\text { perlahan-lahan. }\end{array}$ & $\begin{array}{l}\text { Tertimpa } \\
\text { material }\end{array}$ & 2 & 5 & 10 & $\begin{array}{l}\text { Menggunakan } \\
\text { APD (sarung } \\
\text { tangan, helm, } \\
\text { safety shoes) }\end{array}$ & $\begin{array}{l}\text { Kontrol yang ada } \\
\text { diimplementasikan } \\
\text { dan berfungsi. }\end{array}$ & $75 \%$ \\
\hline
\end{tabular}


Lanjutan Tabel 3.

\begin{tabular}{|c|c|c|c|c|c|c|c|}
\hline \multirow{2}{*}{ Aktivitas Pekerjaan } & \multirow{2}{*}{ Bahaya } & \multicolumn{2}{|c|}{ Penilaian Risiko } & \multirow{2}{*}{$\begin{array}{l}\text { Tingkat } \\
\text { Risiko }\end{array}$} & \multirow{2}{*}{$\begin{array}{c}\text { Pengendalian } \\
\text { Risiko }\end{array}$} & \multirow{2}{*}{ Implementasi } & \multirow{2}{*}{$\begin{array}{c}\text { Penilaian } \\
\text { Pengendalian } \\
\text { Risiko }\end{array}$} \\
\hline & & $\begin{array}{c}\text { Likeli- } \\
\text { hood }\end{array}$ & Severity & & & & \\
\hline $\begin{array}{l}\text { Memastikan bahwa } \\
\text { rigger mengawal } \\
\text { material/bahan yang } \\
\text { akan diangkat atau } \\
\text { dipindahkan selama } \\
\text { proses pengoperasian. }\end{array}$ & $\begin{array}{l}\text { Tertimpa } \\
\text { material }\end{array}$ & 2 & 5 & 10 & $\begin{array}{l}\text { Menggunakan } \\
\text { APD (sarung } \\
\text { tangan, helm, } \\
\text { safety shoes) }\end{array}$ & $\begin{array}{l}\text { Kontrol yang ada } \\
\text { diimplementasikan } \\
\text { dan berfungsi. }\end{array}$ & $75 \%$ \\
\hline $\begin{array}{l}\text { Memastikan beban/ } \\
\text { material yang } \\
\text { telah diangkat atau } \\
\text { dipindahkan akan di } \\
\text { turunkan di tempat } \\
\text { yang aman dan sesuai }\end{array}$ & Terjepit & 3 & 3 & 9 & $\begin{array}{l}\text { Menggunakan } \\
\text { APD (sarung } \\
\text { tangan, helm, } \\
\text { safety shoes) }\end{array}$ & $\begin{array}{l}\text { Persyaratan } \\
\text { kontrol yang ada } \\
\text { diimplemntasikan } \\
\text { dengan cukup baik, }\end{array}$ & $65 \%$ \\
\hline
\end{tabular}

Tabel 4. Penilaian Risiko Sisa pada Pengoperasian Alat Overhead Crane Double Girder

\begin{tabular}{|c|c|c|c|c|c|c|}
\hline $\begin{array}{c}\text { Aktivitas } \\
\text { Pekerjaan }\end{array}$ & Bahaya & $\begin{array}{c}\text { Tingkat } \\
\text { Risiko }\end{array}$ & $\begin{array}{c}\text { Pengendalian } \\
\text { Risiko }\end{array}$ & Implementasi & $\begin{array}{c}\text { Penilaian } \\
\text { Pengendalian }\end{array}$ & $\begin{array}{c}\text { Risiko } \\
\text { Sisa }\end{array}$ \\
\hline $\begin{array}{l}\text { Memastikan berat } \\
\text { beban/material } \\
\text { yang akan diangkat/ } \\
\text { dipindahkan tidak } \\
\text { melebihi SWL }\end{array}$ & $\begin{array}{l}\text { Tergores } \\
\text { material }\end{array}$ & 6 & $\begin{array}{l}\text { Menggunakan APD } \\
\text { (sarung tangan, } \\
\text { helm, safety shoes) }\end{array}$ & $\begin{array}{l}\text { Persyaratan } \\
\text { kontrol yang ada } \\
\text { diimplementasikan } \\
\text { dengan cukup } \\
\text { baik, }\end{array}$ & $65 \%$ & 2,1 \\
\hline $\begin{array}{l}\text { Memilih sling }+ \\
\text { segel yang akan } \\
\text { digunakan untuk } \\
\text { mengangkat atau } \\
\text { memindahkan } \\
\text { material atau bahan }\end{array}$ & $\begin{array}{l}\text { Tergores } \\
\text { material }\end{array}$ & 6 & $\begin{array}{l}\text { Menggunakan APD } \\
\text { (sarung tangan, } \\
\text { helm, safety shoes) }\end{array}$ & $\begin{array}{l}\text { Persyaratan } \\
\text { kontrol yang ada } \\
\text { diimplemntasikan } \\
\text { dengan cukup } \\
\text { baik. }\end{array}$ & $65 \%$ & 2,1 \\
\hline $\begin{array}{l}\text { Menggunakan klem } \\
\text { untuk mengikat } \\
\text { beban/material yang } \\
\text { akan diangkat atau } \\
\text { di pindahkan. }\end{array}$ & $\begin{array}{l}\text { Terjepit } \\
\text { material }\end{array}$ & 9 & $\begin{array}{l}\text { Menggunakan APD } \\
\text { (sarung tangan, } \\
\text { helm, safety shoes) }\end{array}$ & $\begin{array}{l}\text { Persyaratan } \\
\text { kontrol yang ada } \\
\text { diimplementasikan } \\
\text { dengan cukup } \\
\text { baik. }\end{array}$ & $65 \%$ & 3,15 \\
\hline $\begin{array}{l}\text { Memastikan posisi } \\
\text { beban/material } \\
\text { yang akan di angkat } \\
\text { atau dipindahkan } \\
\text { mempunyai posisi } \\
\text { tegak lurus dengan } \\
\text { hook }\end{array}$ & $\begin{array}{l}\text { Terkena } \\
\text { ayunan } \\
\text { material }\end{array}$ & 15 & $\begin{array}{l}\text { Menggunakan APD } \\
\text { (sarung tangan, } \\
\text { helm, safety shoes) }\end{array}$ & $\begin{array}{l}\text { Persyaratan } \\
\text { kontrol yang ada } \\
\text { diimplemntasikan } \\
\text { dengan cukup } \\
\text { baik. }\end{array}$ & $65 \%$ & 5,25 \\
\hline $\begin{array}{l}\text { Memastikan area/ } \\
\text { lintasan yang } \\
\text { akan dilewati oleh } \\
\text { overhead crane } \\
\text { double girder aman/ } \\
\text { steril. }\end{array}$ & $\begin{array}{l}\text { Tersandung } \\
\text { material }\end{array}$ & 6 & $\begin{array}{l}\text { Melakukan house } \\
\text { keeping pada sisa- } \\
\text { sisa material }\end{array}$ & $\begin{array}{l}\text { Persyaratan } \\
\text { kontrol yang ada } \\
\text { diimplemntasikan } \\
\text { dengan cukup } \\
\text { baik. }\end{array}$ & $65 \%$ & 2,1 \\
\hline $\begin{array}{l}\text { Mengangkat beban/ } \\
\text { material secara } \\
\text { perlahan-lahan. }\end{array}$ & $\begin{array}{l}\text { Tertimpa } \\
\text { material }\end{array}$ & 10 & $\begin{array}{l}\text { Menggunakan APD } \\
\text { (sarung tangan, } \\
\text { helm, safety shoes) }\end{array}$ & $\begin{array}{l}\text { Kontrol yang ada } \\
\text { diimplementasikan } \\
\text { dan berfungsi. }\end{array}$ & $75 \%$ & 2,5 \\
\hline
\end{tabular}


Lanjutan Tabel 3.

\begin{tabular}{|c|c|c|c|c|c|c|}
\hline $\begin{array}{l}\text { Aktivitas } \\
\text { Pekerjaan }\end{array}$ & Bahaya & $\begin{array}{l}\text { Tingkat } \\
\text { Risiko }\end{array}$ & $\begin{array}{c}\text { Pengendalian } \\
\text { Risiko }\end{array}$ & Implementasi & $\begin{array}{c}\text { Penilaian } \\
\text { Pengendalian }\end{array}$ & $\begin{array}{c}\text { Risiko } \\
\text { Sisa }\end{array}$ \\
\hline $\begin{array}{l}\text { Memastikan bahwa } \\
\text { rigger mengawal } \\
\text { material/bahan yang } \\
\text { akan diangkat atau } \\
\text { dipindahkan. }\end{array}$ & $\begin{array}{l}\text { Tertimpa } \\
\text { material }\end{array}$ & 10 & $\begin{array}{l}\text { Menggunakan APD } \\
\text { (sarung tangan, } \\
\text { helm, safety shoes) }\end{array}$ & $\begin{array}{l}\text { Kontrol yang ada } \\
\text { dimplementasikan } \\
\text { dan berfungsi. }\end{array}$ & $75 \%$ & 2,5 \\
\hline $\begin{array}{l}\text { Memastikan beban/ } \\
\text { material yang } \\
\text { telah diangkat atau } \\
\text { dipindahkan akan di } \\
\text { turunkan di tempat } \\
\text { yang aman dan } \\
\text { sesuai }\end{array}$ & Terjepit & 9 & $\begin{array}{l}\text { Menggunakan APD } \\
\text { (sarung tangan, } \\
\text { helm, safety shoes) }\end{array}$ & $\begin{array}{l}\text { Persyaratan } \\
\text { kontrol yang ada } \\
\text { diimplemntasikan } \\
\text { dengan cukup } \\
\text { baik, }\end{array}$ & $65 \%$ & 3,15 \\
\hline
\end{tabular}

Penilaian risiko sisa merupakan tahapan yang juga harus dilaksanakan setelah tahap pengendalian risiko selesai dilaksanakan. Menurut Siswanto (2009) menjelaskan bahwa risiko sisa residual risk adalah risiko yang masih tetap terdapat pada suatu proses pekerjaan yang dilaksanakan meskipun telah dilaksanakan pengendalian risiko. Pada dasarnya setiap risiko yang dihasilkan pada suatu pekerjaan akan tetap menghasilkan risiko sisa, sedangkan cara perhitungan untuk mendapatkan nilai dari risiko sisa adalah sebagai berikut:

Risiko sisa $=\quad(100 \%-\%$ nilai kontrol pengendalian $)$ $\times$ risiko murni

Berdasarkan perhitungan risiko sisa yang dapat dihasilkan, maka tahap selanjutnya adalah melakukan pengkategorian hasil perhitungan yang telah didapat untuk memastikan bahwa risiko sisa yang dihasilkan berada di tingkat risiko sisa rendah, risiko sisa sedang maupun berada di tingkat risiko sisa yang masih tinggi. Apabila nilai tingkat risiko sisa yang dihasilkan berada antara 1 sampai 4 maka termasuk ke dalam tingkat risiko sisa yang rendah, sedangkan apabila nilai tingkat risiko sisa yang dihasilkan berada antara 5-10 maka termasuk ke dalam tingkat risiko sisa sedang dan apabila nilai tingkat risiko sisa yang dihasilkan berada antara 12 sampai 25 maka termasuk ke dalam tingkat risiko yang tinggi. Tabel 4 di atas juga telah menunjukkan hasil perhitungan risiko sisa yang ada pada proses pengoperasian alat overhead crane double girder.

\section{PEMBAHASAN}

Langkah pertama yang dilakukan pada penilaian risiko adalah dengan melakukan identifikasi bahaya.
Menurut Ramli $\left(2010^{\mathrm{a}}\right)$ identifikasi bahaya adalah suatu teknik yang komprehensif untuk mengetahui potensi bahaya terhadap bahan, alat maupun terhadap suatu sistem. Identifikasi bahaya dilakukan dengan lebih menitikberatkan secara visual sehingga kurang mampu untuk dapat melakukan identifikasi bahaya yang lebih terperinci yang berkaitan dengan suatu proses, peralatan dan juga prosedur dalam suatu pekerjaan.

Identifikasi bahaya mempunyai tujuan untuk mengetahui bahaya yang dihasilkan pada setiap tahapan pekerjaan yang dilakukan berdasarkan dari sifat maupun karakteristiknya. Identifikasi bahaya dapat dilakukan dengan mengenali seluruh kondisi yang berpotensi dapat mengakibatkan terjadinya kecelakaan. Menurut Ramli (2010 a) terdapat 3 teknik yang dapat digunakan untuk melakukan identifikasi bahaya pada suatu pekerjaan, yaitu teknik pasif yang merupakan cara mengidentifikasi bahaya dengan menggunakan pengalaman yang dialami sendiri oleh seseorang, sedangkan teknik semiproaktif adalah mengidentifikasi bahaya dengan melihat dari pengalaman yang dialami oleh orang lain dan teknik proaktif.

Teknik yang paling baik yang dapat digunakan dalam melakukan suatu identifikasi bahaya adalah dengan menggunakan teknik proaktif karena dengan menggunakan teknik proaktif ini akan dapat mencari dan menemukan suatu potensi bahaya yang dapat terjadi sebelum bahaya tersebut dapat menyebabkan suatu kecelakaan kerja, bersifat berkelanjutan karena dengan mengetahui bahaya apa saja kah yang terdapat pada pekerjaan tersebut dapat membantu dalam melaksanakan upaya perbaikan, meningkatkan kepedulian terhadap semua pekerja yang ada supaya dapat mengetahui bahaya apa saja kah yang ada 
di tempat kerja dan khususnya bahaya yang ada pekerjaan yang mereka lakukan sehari-hari.

Pekerjaan pengoperasian alat overhead crane double girder melakukan identifikasi bahaya berdasarkan dari jenis bahaya dengan menggunakan salah satu instrumen teknik secara proaktif yaitu dengan menggunakan lembar Job Safety Analysis (JSA). Panduan pengisian JSA berdasarkan pada lembar observasi yang sudah disiapkan untuk dibawa langsung ke lapangan dan melakukan wawancara terhadap 3 orang pihak safety yang ada di sana, 12 operator dari alat overhead crane double girder, 17 juru ikat atau rigger dari alat overhead crane double girder yang ada di divisi kapal niaga PT PAL Surabaya.

Tahapan setelah melakukan identifikasi bahaya pada setiap tahapan pekerjaan adalah dengan melakukan penilaian tingkat risiko yang ada. Menurut Siswanto (2009), penilaian risiko sangat penting untuk dilakukan karena dapat membentuk opini terhadap suatu risiko. Penilaian risiko juga merupakan salah satu upaya yang dapat dilakukan untuk menghitung besarnya suatu risiko dan menetakan suatu risiko tersebut dapat diterima atau kah tidak dapat diterima. Penilaian risiko dapat dilakukan dengan cara melakukan perhitungan perkalian antara nilai dari tingkat kemungkinan (likelihood) dan nilai dari tingkat keparahan (severity).

Evaluasi risiko dapat dilakukan supaya dapat memberi makna pada tingkat risiko yang dihasilkan setelah melakukan perhitungan. Risiko dapat dikategorikan berdasarkan hasil perhitungan tingkat risiko yang dihasilkan dan dapat dikategorikan menjadi tiga tingkatan kategori yaitu, tingkat risiko rendah apabila berdasarkan hasil perhitungan memiliki nilai antara 1 sampai 4 , sedangkan apabila berdasarkan hasil perhitungan memiliki nilai antara 5 sampai 10 maka termasuk ke dalam tingkat risiko yang sedang dan apabila berdasarkan hasil perhitungan memiliki nilai antara 12 sampai 25 maka termasuk ke dalam kategori tingkat risiko yang tinggi (Siswanto, 2009).

Pengoperasian alat overhead crane double girder dari 8 risiko yang ditemukan, 7 termasuk ke dalam tingkat risiko yang sedang dan 1 termasuk ke dalam tingkat risiko yang tinggi. Risiko yang tinggi memiliki arti bahwa tugas tidak boleh dilanjutkan, di mana harus dilakukan telaah ulang terhadap pekerjaan tersebut atau melakukan perhitungan pengendalian tahap lanjut yang sesuai supaya dapat mengurangi dampak dari risiko yang dapat terjadi.
Pengendalian risiko yang dilakukan harus dinilai ulang keefektifannya sebelum dapat dimulainya lagi suatu pekerjaan tersebut. Risiko sedang memiliki arti bahwa tugas yang diberikan kepada operator hanya dapat dilanjutkan setelah mendapat otorisasi manajemen yang tepat setelah pihak perusahaan berkonsultasi dengan tenaga ahli dan juga tim penilai. Tugas yang dilaksanakan harus dirancang kembali untuk memperhitungkan bahaya yang terjadi atau harus dapat mengurangi risiko yang dapat terjadi lebih lanjut sebelum dimulainya suatu pekerjaan (Ramli, 2010).

Pengendalian risiko dan penilaiannya merupakan tahap penting dari Risk Management. Menurut OHSAS 18001 dalam Ramli $\left(2010^{\mathrm{b}}\right)$, macam pengendalian bahaya K3 antara lain pengendalian secara eliminasi, substitusi, teknik engineering, administratif dan penyediaan Alat Pelindung Diri (APD). Dari hasil perhitungan tingkat risiko awal ditemukan bahwa terdapat 8 jenis risiko yang ada dan telah dilaksanakan pengendalian terhadap keseluruhan risiko yang ada, baik risiko yang sedang maupun tinggi. Apabila berdasarkan hasil analisa dan evaluasi risiko, tingkat risiko nya rendah ataupun sedang yang berarti masih dapat diterima oleh perusahaan, maka pengendalian yang telah dilakukan oleh perusahaan adalah dengan melakukan pemantauan dan monitoring secara berkala terhadap setiap proses dan pelaksanaan dari tahapan pekerjaan yang ada.

Salah satu risiko yang ada yaitu tertimpa material yang termasuk ke dalam tingkatan risiko sedang, maka pihak perusahaan telah melakukan pengendalian dengan selalu melakukan pengawasan serta memastikan pekerja yang terlibat dalam pekerjaan tersebut menggunakan alat pelindung diri (APD) yang disediakan oleh perusahaan seperti helm, sarung tangan dan juga safety shoes, selain itu pihak perusahaan juga telah berkoordinasi antara pihak safety yang ada dengan operator dan juga rigger dalam pengoperasian alat overhead crane double girder.

Berdasarkan hasil analisa dan evaluasi risiko, apabila tingkat risiko yang didapatkan tinggi maka diperlukan pengendalian yang lebih lanjut untuk menekan atau menurunkan tingkat risiko yang ada. Misalnya pada risiko terkena ayunan material, maka pengendalian yang sudah dilakukan oleh pihak perusahaan adalah dengan berusaha menekan likelihood yang ada, salah satunya dengan melakukan pendekatan secara administratif yaitu menggunakan pendekatan manusia terlebih dahulu 
dengan memberikan pelatihan kepada operator dan juga pada rigger mengenai cara kerja yang aman dan prosedur keselamatan.

Tahapan setelah melakukan pengendalian dengan menekan likelihood, maka tahap selanjutnya pengendalian yang dilakukan perusahaan adalah dengan menekan konsekuensi yang ada. Salah satu metode pendekatan yang digunakan adalah dengan penyediaan alat pelindung diri seperti sarung tangan dan juga helm yang disediakan oleh pihak perusahaan untuk mengurangi dampak atau konsekuensi dari kejadian yang berpotensi bahaya seperti terkena ayunan material yang sedang diangkat ataupun dipindahkan.

Jenis pengendalian yang paling banyak diimplementasikan oleh pihak perusahaan untuk mengurangi dampak atau konsekuensi dari suatu kejadian adalah jenis pengendalian yaitu penyediaan alat pelindung diri (APD) dengan penilaian penerapan pengendalian risiko yang ada sebesar $75 \%$, yang berarti kontrol yang ada telah diimplementasikan dan berfungsi. Akan tetapi masih ada celah jelas yang harus diperbaiki oleh pihak perusahaan.

Penyediaan alat pelindung diri yang ada adalah dengan menyediakan fasilitas seperti helm, sarung tangan dan juga safety shoes yang diberikan kepada setiap pekerja yang ada dan terlibat dalam setiap tahapan proses pengoperasian alat overhead crane double girder serta pihak safety yang ada selalu melakukan pengawasan terhadap pekerja supaya menggunakan alat pelindung diri yang telah disediakan oleh pihak perusahaan dan mengingatkan apabila melihat pekerja yang menggunakan alat pelindung diri kurang sesuai dengan mestinya.

Tahapan terakhir yang dilakukan adalah melakukan penilaian risiko sisa, di mana tahap penilaian risiko sisa merupakan suatu tahapan penilaian suatu risiko yang masih ada meskipun telah dilakukan suatu pengendalian pada risiko tersebut. Risiko sisa akan menunjukkan gambaran keefektifitasan upaya pengendalian risiko yang telah dilakukan oleh pihak perusahaan selama ini.

Berdasarkan hasil penilaian risiko sisa pada pengoperasian dari alat overhead crane double girder, dari 8 risiko yang ada terdapat 7 risiko yang termasuk ke dalam tingkat risiko sisa yang rendah. Hal ini berarti pengendalian tambahan tidak diperlukan dan yang perlu diperhatikan adalah menemukan jalan keluar yang lebih data menghemat biaya atau peningkatan yang tidak membutuhkan biaya tambahan yang besar. Pemantauan diperlukan untuk memastikan bahwa pengendalian risiko yang dilaksanakan telah diterapkan secara baik, benar dan sesuai dengan prosedur yang ada.

Hasil penilaian risiko sisa menunjukkan 1 risiko termasuk ke dalam tingkat risiko sisa yang sedang. Hal ini berarti bahwa diperlukan tindakan untuk mengurangi risiko yang ada, kemudian diperlukan perencanaan program pengendalian risiko yang baik serta perhitungan yang teliti supaya tindakan pengendalian yang dibuat dapat efektif, efisien dan sesuai dengan tujuan yang diinginkan oleh pihak perusahaan dan sudah tidak terdapat lagi risiko sisa yang masih termasuk ke dalam tingkat risiko yang tinggi.

\section{SIMPULAN}

Berdasarkan hasil dari identifikasi bahaya yang telah dilakukan, dari 8 tahapan pekerjaan yang terdapat 8 risiko yang terdiri dari 7 risiko tingkat sedang dan 1 risiko tingkat tinggi. Pengendalian risiko yang telah paling banyak diimplementasikan oleh pihak perusahaan adalah dengan penyediaan alat pelindung diri (APD) seperti helm, sarung tangan dan safety shoes kepada setiap pekerja yang terlibat dalam suatu proses pekerjaan, sedangkan dari hasil penilaian risiko sisa yang ada didapatkan hasil terdapat 7 risiko sisa yang termasuk ke dalam tingkat risiko sisa yang rendah dan 1 risiko sisa yang termasuk ke dalam tingkat risiko yang sedang serta sudah tidak terdapat lagi risiko sisa yang masih termasuk ke dalam tingkat risiko sisa yang tinggi.

\section{DAFTAR PUSTAKA}

Anizar. 2009. Teknik Keselamatan dan Kesehatan Kerja di Industri. Yogyakarta: Graha Ilmu.

Bikatofani, Ryan. R. 2015. Penilaian Risiko Kecelakaan Kerja pada Pengoperasian Overhead Crane Double Girder di Divisi Kapal Niaga PT PAL Surabaya. Skripsi. Surabaya. Universitas Airlangga.

Bird, F. 1990. Practical Loss Control Management, Loganville, Georgia, USA; Published by Institute Press.

Depnakertrans RI. 2012. Keputusan Menteri Tenaga Kerja dan Transmigrasi Nomor per. 05/men/1985. Jakarta; Depnakertrans.

Depnakertrans RI. 2012. Undang-Undang no. 18 tahun 1999 tentang jasa konstruksi. Jakarta. 
Depnakertrans RI. 2012. Peraturan Menteri Tenaga Kerja dan Transmigrasi Nomor per. 09/men/ VII/2010. Jakarta; Depnakertrans.

Kemenakertrans RI. 2011. Himpunan Peraturan Perundang-Undangan Keselamatan dan Kesehatan Kerja. Jakarta.

Lestari, D.A. 2013. Penilaian risiko pada Pengoperasian Overhead Crane (OHC) di workshop fabrikasi PT Bangun Sarana Baja Gresik. Surabaya; Universitas Airlangga.

Ramli, S. 2010a. Pedoman Praktis Manajemen Risiko dalam Perspektif K3. Jakarta; Dian Rakyat.

Ramli, S. 2010 . Sistem Manajemen Keselamatan \& Kesehatan Kerja K3 OHSAS risk management. Jakarta; Dian Rakyat.
Reason, J. 1997. Managing the Risk of Organizational Accidents, England; Ashgate Publishing Limited.

Siswanto, A. 2009. Risk Management. Surabaya; Balai Hiperkes dan Keselamatan Kerja Jawa Timur.

Soputan, Gabby, E.M. 2014. Manajemen Risiko Kesehatan dan Keselamatan Kerja (K3) (Studi Kasus pada Pembangunan Gedung SMA Eben Haezar). Manado: Universitas Sam Ratulangi.

Wicaksono, Iman. K. 2011 Manajemen Risiko K3 (Keselamatan dan Kesehatan Kerja) pada Proyek Pembangunan Apartemen Puncak Permai Surabaya. Surabaya: Institut Teknologi Sepuluh November. 